\title{
PENGARUH RASIO PERPUTARAN KAS DAN PERPUTARAN PERSEDIAAN TERHADAP PROFITABILITAS PADA PT MUSTIKA RATU TbK YANG TERDAFTAR DI BURSA EFEK INDONESIA PERIODE 2007-2017
}

\author{
DR. DEFRIZAL, SE, MM., \\ Dosen Fakultas Ekonomi Universitas Bandar Lampung \\ Jl. Z.A Pagar Alam No. 26 Labuhan Ratu Bandar Lampung 35142 \\ Telp. 0721-701979 Fax. 0721-701463
}

\author{
FELICIA MAGDALENA \\ Alumni Fakultas Ekonomi Universitas Bandar Lampung \\ Jl. Z.A Pagar Alam No. 26 Labuhan Ratu Bandar Lampung 35142 \\ Telp. 0721-701979 Fax. 0721-701463
}

\begin{abstract}
ABSTRAK
Felicia Magdalena, Pengaruh Rasio Perputaran Kas Dan Perputaran Persediaan Terhadap Profitabilitas Pada PT Mustika Ratu Tbk Yang Terdaftar di Bursa Eefek Indonesia Periode 20072017. Tujuan dilakukan penelitian ini adalah untuk mengetahui pengaruh tingkat perputaran kas, perputaran persediaan pada profitabilitas PT Mustika Ratu Tbk yang terdaftar di Bursa Efek Indonesia tahun 20072017, serta untuk mengetahui pengaruh tingkat perputaran kas dan perputaran persediaan terhadap profitabilitas secara parsial maupun simultan pada PT Mustika Ratu yang terdaftar di Bursa Efek Indonesia tahun 2007 -2017. Variabel yang digunakan dalam penelitian ini terdiri dari variabel independen dan dependen, variabel independen yang digunakan adalah perputaran kas dan perputaran persediaan, variabel dependen yang digunakan adalah profitabilitas. Periode penelitian ini yaitu dari tahun 2007 sampai dengan 2017. Data yang digunakan adalah data sekunder yang diperoleh dari Bursa Efek Indonesia (BEI). Metode yang digunakan yaitu pengujian statistik dengan analisis regresi berganda dengan menggunakan Eviews 9.

Hasil Penelitian ini menunjukan bahwa perputaran kas secara parsial berpengaruh negatif terhadap profitabilitas, perputaran persediaan secara parsial berpengaruh positif terhadap profitabilitas. Secara simultan Perputaran kas dan perputaran persediaan berpengaruh terhadap profitabilitas.
\end{abstract}

Kata kunci : Perputaran Kas, Perputaran Persediaan, Profitabilitas.

\footnotetext{
ABSTRACT

This study examines the influence of cash turnover and inventory turnover on profitability in manufacture company of mustika ratu tbk listed in Indonesia Stock Exchange in 2007-2017, as well as to determine the effect of cash turnover and inventory turnover on profitability partially or simultaneously on the manufacture company of mustika ratu tbk listed in Indonesia Stock Exchange in 2007-2017. The variables used in this study consisted of independent and dependent variables.The independent variables used are cash turnover and inventory turnover, while the dependent variable used is the profitability variable. This research period is from 2007 to 2017.The data used is secondary data obtained from the Indonesia Stock Exchange. The method used is the statistical testing and regression of panel data using Eviews 9.

These results indicate that the turnover of accounts cash partially negative effect on profitability, inventory turnover is partially positive effect on profitability. Simultaneously cash turnover and inventory turnover have a effect on profitability.

Keywords : Cash Turnover, Inventory Turnover, Profitability.
} 


\section{PENDAHULUAN}

Perusahaan harus mempunyai tujuan dan sasaran yang hendak dicapai. Salah satu tujuan dari perusahaan adalah untuk memperoleh laba yang maksimal. Laba yang diperoleh perusahaan dapat menjadi ukuran yang digunakan untuk menilai berhasil atau tidaknya manajemen suatu perusahaan.

Salah satu rasio yang digunakan perusahaan untuk mengukur laba adalah rasio profitabilitas. Profitabilitas sebagai kemampuan suatu perusahaan untuk menghasilkan laba. Salah satu ukuran profitabilitas yang paling penting adalah laba bersih (Astuti dalam Winarso, 2014).

Profitabilitas yang tinggi dapat diperoleh perusahaan dengan memperhatikan faktor-faktor yang dapat mempengaruhi, diantaranya adalah perputaran piutang dan perputaran persediaan. Piutang usaha ini muncul karena adanya penjualan kredit menurut Harjito dan Martono dalam Hoiriya dan Marsudi Lestariningsih (2015) Semakin banyak volume penjualan oleh perusahaan maka semakin besar pula perusahaan akan memperoleh keuntungan.

$$
\text { Menurut Bambang Riyanto (2011) }
$$

perputaran kas adalah perbandingan antara penjualan dengan jumlah kas rata-rata. Jumlah kas dapat pula dihubungkan dengan jumlah penjualan atau salesnya. Semakin tinggi perputaran kas akan semakin baik dalam penggunaan kas dan keuntungan yang diperoleh akan semakin besar (Kasmir, 2008).

Persediaan mempermudah atau memperlancar jalannya operasi perusahaan yang harus dilakukan secara berturut - turut untuk memproduksi barang barang serta mendistribusikannya kepada konsumen. Perputaran persediaan merupakan salah satu hal yang harus diperhatikan oleh perusahaan dalam operasi perusahaan itu sendiri. Persediaan harus dikelola dengna baik karena persediaan yang optimal dapat meningkatkan efektifitas perusahaan sehingga meningkatkan keuntungan yang diperoleh perusahaan. Untuk mempertahankan penjualan, perusahaan harus menjamin tersedianya persediaan (Ridwan, 2007)

Tahun 2017 PT Mustiak Ratu Tbk memiliki perputaran kas terbesar 14.59 kali dan perputaran kas terendah pada tahun 2007 sebesar 3.00 kali. Perputaran persediaan PT Mustika Ratu Tbk terbesar pada tahun 2011 sebesar 3.97 kali dan terendah pada tahun 2017 sebesar 1.44 kali.

Return On Asset 3 tahun terakhir PT Mustika Ratu Tbk dari tahun 2015-2017, pada tahun 2015 sebesar $0.002,2016$ sebesar -0.011 dan 2017 sebesar -0.003 .

Beberapa penelitian tentang pengaruh antara perputaran piutang dan perputaran persediaan dengan profitabilitas perusahaan adalah penelitian oleh Nuriyani dan Rachma Zannati yang meneliti pengaruh perputaran kas dan perputaran piutang terhadap profitabilitas perusahaan sub sektor food and beverages yang terdaftar di BEI periode 2012-2016 memperoleh hasil secara silmutan perputaran kas dan piutang berpengaruh secara signifikan profitabilitas, secara persial perputaran kas memberikan pengaruh positif yang signifikan sedangkan perputaran piutang secara persial tidak berpengaruh terhadap profitabilitas.

Penelitian lain adalah oleh Surya dkk (2017) yang meneliti pengaruh perputaran kas dan perputaran persediaan terhadap profitabilitas Perusahaan Otomotif yang Terdaftar di BEI memperoleh hasil bahwa perputaran kas dan perputaran persediaan secara simultan tidak berpengaruh terhadap profitabilitas pada perusahaan otomotif dan komponennya dan secara parsial masingmasing variabel tidak berpengaruh terhadap profitabilitas Perusahaan Otomotif yang terdaftar di BEI.

Penelitian ini akan menggunakan PT Mustika RAtu Tbk yang terdaftar di Bursa Efek Indonesia (BEI) tahun 2007-2017.

Berdasarkan uraian latar belakang maka penulis tertarik untuk melakukan penelitian dengan judul :"Pengaruh Rasio Perputaran Kas dan Perputaran Persediaan terhadap Profitabilitas pada PT Mustika Ratu Tbk yang Terdaftar di Bursa Efek Indonesia Periode 2007-2017."

\section{RUMUSAN MASALAH}

Berdasarkan uraian latar belakang diatas, maka penulis merumuskan permasalahan sebagai berikut, yaitu :

1. Apakah perputaran kas berpengaruh terhadap profitabilitas pada perusahaan PT Mustika Ratu Tbk terdaftar di Bursa Efek Indonesia (BEI) Periode 20072017 ?

2. Apakah perputaran persediaan berpengaruh terhadap profitabilitas pada perusahaan PT Mustika Ratu Tbk terdaftar di Bursa Efek Indonesia (BEI) Periode 20072017 ?

3. Apakah perputaran kas dan perputaran persediaan secara bersama-sama berpengaruh terhadap profitabilitas Perusahaan PT Mustika Ratu Tbk yang terdaftar di Bursa Efek Indonesia (BEI) Periode 20072017 ?

Adapun tujuan dari penelitian ini adalah

1. Untuk menganalisis apakah perputaran kas berpengaruh terhadap profitabilitas?

2. Untuk menganalisis apakah perputaran kas berpengaruh terhadap profitabilitas?

3. Untuk menganalisis apakah peputaran kas dan peputaran persediaan secara bersama - sama berpengaruh terhadap profitabilitas? 


\section{TINJAUAN PUSTAKA Profitabilitas}

Pengertian profitabilitas menurut Sipangkar (2009) adalah Rasio profitabilitas dianggap sebagai alat yang paling valid dalam mengukur hasil pelaksanaan operasi perusahaan karena rasio profitabilitas merupakan alat pembanding pada berbagai alternatif investasi yang sesuai dengan tingkat risiko. Menurut Wiagustini dalam Sanjaya dkk (2015) menyatakan profitabilitas merupakan suatu kemampuan perusahaan untuk mewujudkan suatu keuntungan bagi perusahaan atau merupakan suatu pengukuran akan efektivitas pengelolaan perusahaan dalam mengelola manjemennya Menurut Mulyadi dalam Sanjaya dkk (2015) terdapat jenis-jenis rasio profitabilitas yaitu sebagai berikut: Gross Profit Margin (GPM), Net Profit Margin (NPM), Return On Asset (ROA), dan Return On Equiy (ROE)

Penelitian ini menggunakan Return On Assets sebagai proksi dari profitabilitas. Hal ini didasarkan pada pertimbangan bahwa ROA dapat mengukur keefektifitasan perusahaan dalam menghasilkan laba, sehingga memberikan gambaran bagi para investor dalam mengambil keputusan investasi. Efisien atau tidaknya suatu perusahaan dapat diketahui dengan membandingkan laba yang diperoleh dengan kekayaan yang menghasilkan laba (profitabilitas).

\section{Perputaran Kas}

Perputaran kas adalah perputaran sejumlah modal kerja yang tertanam dalam kas dan bank dalam satu periode akuntansi. Perputaran kas diketahui dengan membandingkan antara jumblah pendapatan dan pemberian pinjaman dengan jumlah kas rata-rata. Menurut Bamban Riyanto (2011) perputaran kas adalah perbandingkan antara penjualan dengan jumblah kas rata-rata. Jumlah kas dapat pula dihubungkan dengan jumlah penjualan atau salesnya. Perbandingan antara penjualan dengan jumlah kas rata-rata menggambarkan tingkat perputaran kas (cash Turnover).

Tingkat perputaran kas merupakan ukuran efesiensi penggunaan kas yang dilakukan oleh perusahaan. Karena tingkat perputaran kas menggambarkan kecepatakn arus kas kembalinya kas telah ditanamkan di dalam model kerja. Dalam mengukur tingkat perputaran kas, sumber masuknya kas yang telah tertanam dalam model kerja adalah berasal dari aktivitas operasional perusahaan.

\section{Perputaran Persediaan}

Menurut Moeljadi dalam Suarnami dkk (2014), rasio perputaran persediaan digunakan untuk mengukur perjalanan persediaan sampai kembali menjadi uang kas. Rasio ini dihitung dengan membagi penjualan dengan persediaan atau harga pokok dengan persediaan. Rasio Perputaran Persediaan merupakan rasio yang digunakan untuk mengukur berapa kali dana yang ditanam dalam persediaan ini berputar dalam suatu periode. Apabila rasio yang diperoleh tinggi, ini menunjukkan perusahaan bekerja secara efesien dan likuid persediaan semakin baik. Demikian pula apabila perputaran persediaan rendah berarti perusahaan bekerja secara tidak efesien atau tidak produktif dan banyak barang persediaan yang menumpuk.

\section{Penelitian Terdahulu}

Penelitian terdahulu merupakan bahan acuan yang dapat mendukung penelitian. Berikut ini merupakan ringkasan dari penelitian terdahulu.

1. Reny Febriani (2017) melakukan penelitian pengaruh perputaran kas terhadap profitabilitas pada perusahaan makan dan minum yang terdaftar di bei dengan hasil secara persial menunjukan bahwa perputaran kas tidak berpe

2. Surya, Sarjito, Ruly Ruliana, dan Dedi Rossidi Soetama (2017) melakukan penelitian mengenai pengaruh Perputaran Kas, Perputaran Persediaan. terhadap profitabilitas Perusahaan Otomotif yang Terdaftar di BEI. Hasil penelitian menunjukkan Perputaran kas dan perputaran persediaan secara simultan tidak berpengaruh terhadap profitabilitas. Begitu juga secara parsial masing -masing variabel tidak berpengaruh terhadap profitabilitas.

3. Nuriyani dan Rachma Zannati yang meneliti pengaruh perputaran kas dan perputaran piutang terhadap profitabilitas perusahaan sub sektor food and beverages yang terdaftar di BEI periode 2012-2016 memperoleh hasil secara silmutan perputaran kas dan piutang berpengaruh secara signifikan profitabilitas, secara persial perputaran kas memberikan pengaruh positif yang signifikan sedangkan perputaran piutang secara persial tidak berpengaruh terhadap profitabilitas.

4. Putri Ayu Diana (2016) melakukan penelitian pengaruh perputaran kas, piutang dan persediaan terhadap profitabilitas pada perusahaan semen yang terdaftar di Bursa Efek Indonesia (BEI), Hasil Penelitian Menyatakn bahwa perputaran kas berpengaruh signifikan terhadap profitabilitas, perputaran piutang tidak berpengaruh signifikan terhadap profitabilitas dan perputaran persediaan berpengaruh signifikan terhadap profibilitas.

5. Andi Zulfikar Syukuriandi (2015) melakukan penelitian pengaruh perputaran kas, piutang dan persediaan terhadap profitabilitas pada perusahaan konstruksi yang terdaftar di Bursa Efek Indonesia (BEI). Hasil penelitian Perputaran kas berpengaruh signifikan terhadap profitabilitas sedangkan perputaran piutang menunjukkan bahwa variable perputaran piutang berpengaruh negatif dan tidak signifikan terhadap profitabilitas dan perputaran 
persediaan berpengaruh positif dan signifikan terhadap profitabilias

\section{KERANGKA PEMIKIRAN \\ kerangka Pemikiran}

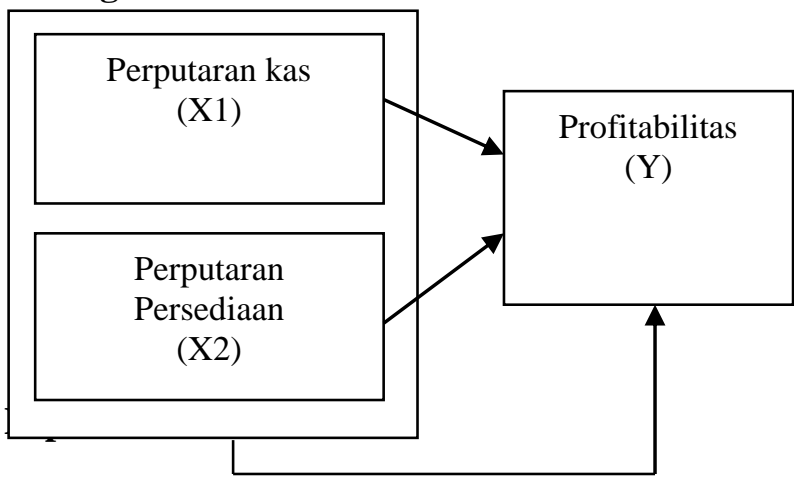

H1 : Perputaran kas berpengaruh positif terhadap profitabilitas pada PT Mustika Ratu Tbk.

$\mathrm{H} 2$ : Perputaran persediaan berpengaruh positif terhadap profitabilitas pada PT Mustika Ratu Tbk.

H3 : Perputaran kas dan perputaran persediaan secara bersama-sama berpengaruh terhadap profitabilitas pada PT Mustika Ratu Tbk.

\section{METODE PENELITIAN \\ Jenis Penelitian}

Jenis penelitian ini termasuk dalam desain penelitian kausal. Penelitian ini dilakukan untuk menguji hipotesis tentang pengaruh dari satu atau beberapa variabel bebas (variabel independen) terhadap variabel terikat (variabel dependen).

\section{Definisi Operasional Variabel Penelitian Variabel Dependen \\ Return On Asset atau ROA (Kasmir,2009):}

$$
\text { Return On Asset }=\frac{\text { Laba Bersih Setelah Pajak }}{\text { Total Aktiva }} \times 100 \%
$$

\section{Variabel Independen}

1. Perputaran kas (Kasmir, 2009)

$$
\text { Perputaran kas }=\frac{\text { Penjualan bersih }}{\text { Rata-rata kas }}
$$

2. Perputaran persediaan (Kasmir, 2009)

$$
\text { PerputaranPersediaan }=\frac{\text { Harga Pokok Penjualan }}{\text { Rata-rata Persediaan }}
$$

\section{Populasi}

Populasi dalam penelitian ini adalah PT Mustika Ratu Tbk yang terdaftar di Bursa Efek Indonesia.

\section{Sampel}

Sample yang di pergunakan dalam penelitian ini adalah perusahaan PT Mustika Rati Tbk yang terdaftar di Bursa Efek Indonesia Periode 2007-2017.

\section{Teknik Pengumpulan Data}

Teknik pengumpulan data dalam penelitian ini dilakukan melalui dokumentasi data dan Teknik pengumpulan data menggunakan studi pustaka.

\section{Metode Analisis Data}

1. Analisis Statistik Deskriptif

2. Analisis Regresi Linear Berganda

3. Uji Hipotesis

a. Uji Signifikansi Parameter Individual (Uji Statistik T)

b. Uji Signifikansi Simultan (Uji Statistik F)

c. Koefisien Determinasi $\left(\mathrm{R}^{2}\right)$

\section{HASIL DAN PEMBAHASAN}

\section{A. Analisis Deskriptif}

Statistik Deskriptif Variabel Profitabilitas, Perputaran kas, dan Perputaran Persediaan.

\begin{tabular}{|c|c|c|c|}
\hline & Profitabilitas & CTO & INTO \\
\hline Mean & 0.031364 & 7.364216 & 2.691937 \\
\hline Median & 0.035000 & 6.234160 & 2.458723 \\
\hline Maximum & 0.068000 & 14.59567 & 3.972266 \\
\hline Minimum & -0.015000 & 3.008284 & 1.447624 \\
\hline Std. Dev. & 0.033356 & 3.932436 & 0.791059 \\
\hline Skewness & -0.164220 & 0.537778 & 0.036868 \\
\hline Kurtosis & 1.332748 & 1.978179 & 2.026650 \\
\hline Jarque-Bera & 1.323484 & 1.008765 & 0.436721 \\
\hline Probability & 0.515952 & 0.603878 & 0.803835 \\
\hline Sum & 0.345000 & 81.00638 & 29.61131 \\
\hline Sum Sq. Dev. & 0.011127 & 154.6405 & 6.257742 \\
\hline Observations & 11 & 11 & 11 \\
\hline
\end{tabular}

Merupakan gambaran terhadap deskripsivariabelvariabel dalam penelitian. Secara umum PT Mustika Ratu Tbk digambarkan melalui profitabilitas yang diperoleh selama periode 2007-2017. Tingkat profitabilitas sebesar 0.031364 artinya kemampuan perusahaan memperoleh laba dengan total aktiva yang dimiliki adalah sebesar $3,13 \%$ dapat dicapai melalui perputaran kas pada tingkat 7.364216 dan dapat dicapai melalui perputaran persediaan pada tingkat 2.691937 Tingkat profitabilitas sebesar 0.035000 artinya kemampuan perusahaan memperoleh laba dengan total aktiva yang dimiliki adalah sebesar 3.5\% dapat dicapai melalui perputaran kas pada tingkat 6.234160 , dan dapat dicapai melalui perputaran persediaan pada tingkat 2.458723 . Tingkat profitabilitas tertinggi sebesar 0,068000 artinya kemampuan perusahaan 
memperoleh laba dengan total aktiva yang dimiliki adalah sebesar 6,8\% dapat dicapai melalui perputaran kas pada tingkat 14.59567 dan dapat dicapai melalui perputaran persediaan pada tingkat 3.972266. Kemudian, tingkat profitabilitas sebesar -0.015000 dapat dicapai melalui perputaran piutang pada tingkat 3.008284 dan dapat dicapai melalui perputaran persediaan pada tingkat 1.447625 .

TinGkat Profitabilitas sebesar 0.033356 artinya kemampuan perusahaan memperoleh laba dengan total aktiva yang dimiliki adalah sebesar 3,33\% dapat dicapai melalui perputaran kas pada tingkat 3.932436 dan dapat dicapai melalui perputaran persediaan pada tingkat 0.791059 .

\section{B. Pengujian Model}

\section{Uji Normalitas}

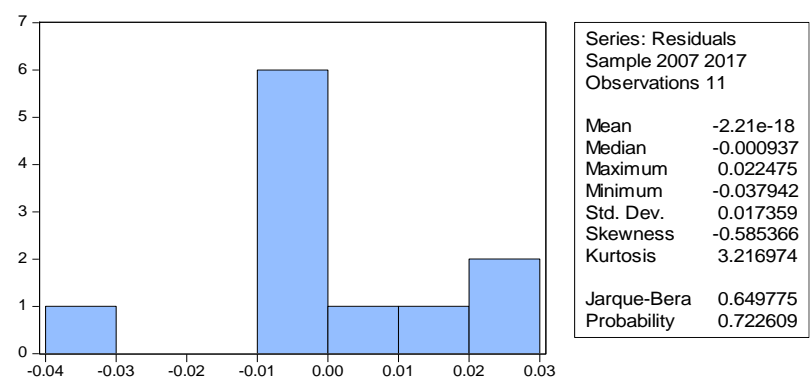

Sumber : Output Eviews

Berdasarkan hasil normalitas di atas bahwa pro babilias sebesar 0.722609 , maka lebih besar dari pada tingkat signifikansi sebesar 0.5 , sehingga dapat disimpulkan data yang saya uji berdistribusi normal.

\section{Uji Multikolonieritas}

\begin{tabular}{|l|l|l|}
\hline & CTO & INTO \\
\hline CTO & 1.000000 & -0.727271 \\
\hline INTO & -0.727271 & 1.000000 \\
\hline
\end{tabular}

Sumber : Lampiran, Output Eviews

Menunjukkan bahwa kedua variabel independen ini tidak terjadi multikolonieritas yang dapat dilihat dari besarnya nilai correlation untuk variabl Perputaran kas dan Perputaran Persediaan sedangkan untuk variabel dependen yaitu profitabilitas kurang dari 0,85 .

\section{Uji Heterokedastisitas.}

\begin{tabular}{ccccc}
\hline \hline Variable & Coefficient & Std. Error & t-Statistic & Prob. \\
\hline \hline C & 0.033721 & 0.027683 & 1.218127 & 0.2579 \\
CTO & -0.000672 & 0.001414 & -0.475483 & 0.6472 \\
INTO & -0.006023 & 0.007029 & -0.856803 & 0.4165 \\
\hline \hline & & & & \\
R-squared & 0.088878 & Mean dependent var & 0.012557 \\
Adjusted R-squared & -0.138902 & S.D. dependent var & 0.011309 \\
S.E. of regression & 0.012069 & Akaike info criterion & -5.769366 \\
Sum squared resid & 0.001165 & Schwarz criterion & -5.660850 \\
Log likelihood & 34.73152 & Hannan-Quinn criter. & -5.837771 \\
F-statistic & 0.390194 & Durbin-Watson stat & 1.790358 \\
Prob(F-statistic) & 0.689137 & & \\
\hline \hline
\end{tabular}

Sumber : Lampiran, Output Eviews versi 9

Model regresi yang baik adalah model yang tidak memiliki heteroskedastisitas, tidak terjadinya heteroskedastisitas ditandai dengan nilai signifikan yang lebih besar dari 0,05 ( Widarjono,2013). Tabel 4.6 memperlihatkan bahwa adjusted R-Squared sebesar 0.138902 dengan $\alpha=0,05$, maka hasil regresi tidak memiliki masalah heterokedastisitas.

\section{Uji Autokolerasi}

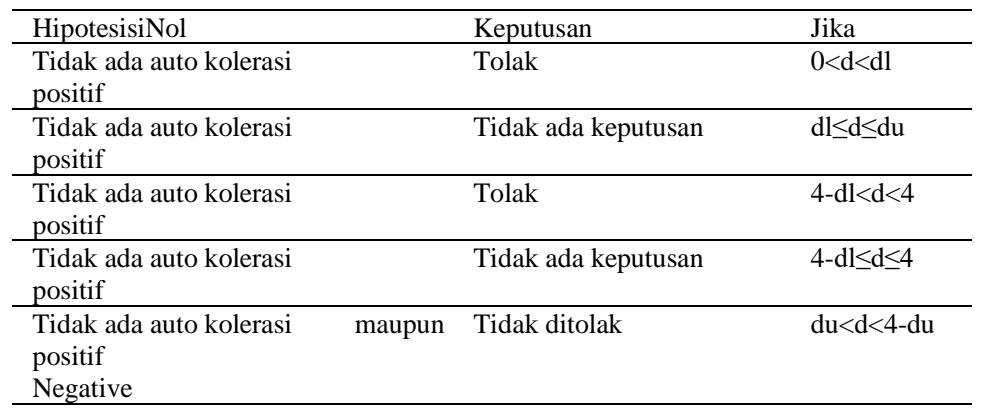

Sumber:Widarjono,

2013

Nilai DW test berdasarkan hasil estimasi adalah sebesar 2.219589 . Nilai dL dan dU pada tingkat signifikansi 0.05 dan dengan sebanyak 2 dan $n$ sebanyak 11 observasi. Nilai dL sebesar 0,7580 dan dU sebesar 1.6044 dapat disimpulkan tidk terdapat autokorelasi positif dan tidak terdapat autokorelasi negatif. Jadi, nilai $\mathrm{du}<\mathrm{d}<4$-du adalah $1.6044<2.219589<2.3956$, sehingga dapaat dikatakan bahwa model regresi ini tidak terjadi autokorelasi baik positif maupun negative dan keputusan dapat diterima (tidak ditolak) 


\section{Hasil Regresi Linear Berganda}

Dependent Variable: PROFITABILITAS

Method: Least Squares

Date: $12 / 11 / 18$ Time: 14:35

Sample: 20072017

Included observations: 11 berpengaruh positif terhadap profitabilitas. Dengan nilai probabilitas sebesar 0,0210 yang berarti berpengaruh signifikan. Karena, nilai probabilitas tersebut kurang dari tingkat $\alpha=5 \%$. Artinya variabel Perputaran Persediaan (Inventory Turnover) berpengaruh positif signifikan terhadap profitabilitas. Maka, $\mathrm{H}_{2}$ diterima bahwa perputaran persediaan berpengaruh positif terhadap profitabilitas.

2.

\section{Uji F}

Dapat dilihat dari Tabel regresi linear berganda

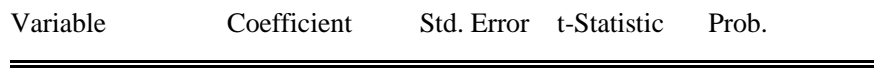

\begin{tabular}{lcccc} 
CTO & -0.000959 & 0.002274 & -0.421572 & 0.6844 \\
INTO & 0.032392 & 0.011304 & 2.865535 & 0.0210 \\
C & -0.048774 & 0.044518 & -1.095615 & 0.3051 \\
\hline \hline
\end{tabular}

$\begin{array}{lrll}\begin{array}{l}\text { R-squared } \\ \text { Adjusted }\end{array} & \begin{array}{l}0.729164 \\ \text { squared }\end{array} & \text { Mean dependent var } & 0.031364 \\ \text { S.E. of regression } & 0.019408 & \text { Akaike info criterion } & -4.819228 \\ \text { Sum squared resid } & 0.003013 & \text { Schwarz criterion } & -4.710711 \\ \text { Log likelihood } & 29.50575 & \text { Hannan-Quinn criter. } & -4.887632 \\ \text { F-statistic } & 10.76910 & \text { Durbin-Watson stat } & 2.219589 \\ \text { Prob(F-statistic) } & 0.005381 & & \end{array}$

Sumber : Output Eviews

Maka dapat dibuat persamaan regresi sebagai berikut. $\mathrm{ROA}=-0.048774+0.044518 \mathrm{CTO}-$ 1,095615INTO

Berdasarkan hasil regresi diatas maka dapat dilihat bahwa ketika CTO (cash turnover) meningkat sebesar 1 dan variable lain maka nilai ROA akan meningkat sebesar 0.044518 . selanjutnya, ketika INTO menurun sebesar 1 dan variable lain tetap maka nilai ROA akan meniurun -1.095615 .

\section{Uji Hipotesis \\ 1. Uji t}

Dapat dilihat dari regresi linear berganda diatas bahwa variable Perputaran kas ( Cash Turnover) memiliki koefisien sebesar -0.000959 yang bearti variabel tersebut berpengaruh negatif terhadap profitabilitas. Dengan nilai probabilitas sebesar 0.6844 yang bearti tidak berpengaruh signifikan. Karena, nilai probabilitas tersebut lebih dari tingkat $\alpha=5 \%$. Artinya variabel Perputaran Kas ( Cash Turnover) tidak berpengaruh signifikan terhadap profitabilitas. Maka, $\mathrm{H}_{1}$ ditolak bahwa perpputaran kas berpengaruh positif terhadap profitabilitas.

Adapun variabel Perputaran Persediaan (Inventory Turnover) memiliki koefisien sebesar 0,032392 yang berarti variabel tersebut diatas menggunakan program eviews 9 diperoleh hasil bahwa probabilitas F-Statistic sebesar 0.005381 yang berarti variabel independen secara simultan berpengaruh terhadap variabel dependen. Karena, nilai probabilitas FStatistic tersebut kurang dari tingkat $\alpha=5 \%$. Artinya terdapat pengaruh yang signifikan antara semua variabel independen terhadap variabel dependen. Maka, $\mathrm{H}_{3}$ diterima bahwa perputaran kas dan perputaran persediaan secara bersama-sama berpengaruh terhadap profitabilitas.

\section{3.. $\quad$ Uji Koefisien Determinasi} diatas menggunakan program Eviews 9 diperoleh hasil $r$ square adalah 0,729164 dan adjusted r-square adalah 0,661455 . Nilai $r$-square menunjukkan bahwa variabel independen yang digunakan dalam penelitian ini hanya mampu menerangkan variasi variabel dependen yaitu profitabilitas sebanyak $72.91 \%$. Sisanya $27.09 \%$ diterangkan oleh variabel lainnya yang tidak termasuk dalam model penelitian. Nilai adjusted $r$ - square menunjukkan bahwa variabel independen yang digunakan dalam penelitian ini hanya mampu menerangkan variasi variabel dependen setelah disesuaikan dengan pengaruh dari variabel independen sebanyak $72,91 \%$. Sisanya sebesar $27,08 \%$ diterangkan oleh variabel lainnya yang tidak termasuk dalam penelitian ini.

\section{SIMPULAN DAN SARAN SIMPULAN}

Penelitian ini memiliki tujuan untuk

mengetahui pengaruh perputaran kas dan perputaran persediaan terhadap profitabilitas pada PT Mustika Ratu Tbk yang terdaftar di Bursa Efek Indonesia Tahun 20072017. Penelitian ini menggunakan regresi linear berganda sebagai alat uji hipotesis dengan program Eviews 9. Berdasarkan penelitian yang telah dilakukkan diperoleh hasil sebagai berikut:

1.Perputaran kas (Cash Turnover) Tidak berpengaruh terhadap profitabilitas pada PT Mustika Ratu Tbk yang terdaftar di Bursa Efek Indonesia Tahun 2007-2017, maka $\mathrm{H}_{1}$ ditolak.

2.Perputaran Persediaan (Inventory Turnover) berpengaruh positif terhadap profitabilitas pada PT Mustika Ratu Tbk yang terdaftar di Bursa Efek Indonesia Tahun 2007-2017, maka $\mathrm{H}_{2}$ diterima. Hal ini
Dapat dilihat dari Tabel regresi linear berganda 
menunjukkan bahwa semakin tinggi perputaran persediaan maka akan meningkatkan profitabilitas.

3.Perputaran Kas (Cash Turnover) dan Perputaran Persediaan (Inventory Turnover) secara simultan berpengaruh terhadap profitabilitas PT Mustika Ratu Tbk yang terdaftar di Bursa Efek Indonesia Tahun 2007-2017, maka $\mathrm{H}_{3}$ diterima. Hal ini menunjukkan bahwa semakin tinggi perputaran kas dan perputaran persediaan maka akan meningkatkan profitabilitas.

\section{SARAN}

1. Bagi Investor

Investor atau calon investor dapat memilih perusahaan dengan melihat tingkat perputaran piutang dan perputaran persediaan sebagai bahan pertimbangan pada saat melakukan keputusan investasi.

2. Bagi Perusahaan

Berdasarkan hasil penelitian ini bahwa PT Mustika Ratu Tbk memiliki tingkat perputaran kas yang tidak berpengaruh terhadap profitabilitas dan perputaran persediaan yang berpengaruh positif terhadap profitabilitas perusahaan yang artinya semakin tinggi perputaran persediaan maka profitabilitas akan meningkat dan semakin baik kinerja keuangan perusahaan. Oleh karena itu, perusahaan sebaiknya mempertahankan keadaan tersebut atau ditingkatkan supaya lebih baik lagi

3. Bagi Peneliti

Untuk peneliti selanjutnya sebaiknya menambah variabel lain untuk mengetahui pengaruhnya terhadap profitabilitas. Karena hasil penelitian ini, variabel independen yang digunakan hanya mampu mampu menerangkan variasi variabel dependen yaitu profitabilitas sebanyak $72.91 \%$. Sisanya $27.09 \%$ diterangkan oleh variabel lainnya yang tidak termasuk dalam model penelitian.

\section{Daftar Pustaka}

Agus Harjito dan Martono,2011. Manajemen Keuangan. Edisi Kedua, Cetakan Pertama, Penerbit EKONISIA, Yogyakarta.

\footnotetext{
Astuti,Dewi.2004.Manajemen Keuangan Perusahaan. Jakarta : Ghalia Indonesia
}

Bambang, Riyanto. 2011. Dasar-dasar pembelanjaan perusahaan. yogyakarta: BPFE

Febriani Reny.2017.”Pengaruh Perputaran Kas Terhadap Profitabilitas Pada Perusahaan Makanan dan Minuman yang Terdaftar di BEI Periode 2011-2015". Jurnal Ilmu dan Riset Akuntansi. Universistas Pakuan.

Kasmir. 2008. Analisis Laporan Keuangan. Jakarta : PT Raja Grafindo Persada.

Ridwan, 2007. Skala Pengukuran Variabelvariabel Penelitian. Bandung : Alfabeta.

Sipangkar,EllysDelfrina.2009."Pengaruh Perputaran Persediaan Terhadap Tingkat Profitabilitas Perusahaan Pada Perusahaan Otomotif yang Terdaftar di Bursa Efek Indonesia”.

Surya,S.Ruliana,R.\&Soetama,D.R.2017.

"Pengaruh Perputaran Kas dan Perputaran Persediaan Terhadap Profitabilitas". Jurnal Ilmu Akuntansi. Sekolah Tinggi Ilmu Ekonomi STAN Indonesia Mandiri. Vol. 10.

Wiagustini, Luh Putu. 2014. Dasar-dasar ManajemeKeuangan. Denpasar:Udayana University Press.

Syukuriandi,A.,Z.2015.’Perngaruh

Perputaran Kas Piutang dan Persediaan Terhadap Profitabilitas pada perusahaan Konstruksi. Jurnal Bisnis dan Kewirausahaan. Sekolah Ilmu Eknomi Nobel Indonesia. Vol. 6, No. 4.

--WWW.idx.co.id 